\title{
Yield Components of Adama Red Onion (Allium cepa L.) Cultivar as Affected by Intra-row Spacing Under Irrigation in Fiche Condition
}

\author{
Sara Belay, Daniel Mideksa, Solomon Gebrezgiabher, Weldemariam Seifu* \\ Department of Horticulture, College of Veterinary Medicine and Agriculture, Addis Ababa University, Fiche, Ethiopia
}

Email address:

whamlove@gmail.com (W. Seifu)

\section{To cite this article:}

Sara Belay, Daniel Mideksa, Solomon Gebrezgiabher, Weldemariam Seifu. Yield Components of Adama Red Onion (Allium cepa L.) Cultivar as Affected by Intra-row Spacing Under Irrigation in Fiche Condition. Plant. Vol. 3, No. 6, 2015, pp. 75-79. doi: 10.11648/j.plant.20150306.13

\begin{abstract}
A field experiment was conducted at Addis Ababa University, Selale Campus Horticulture department demonstration farm to assess the effect of plant density (intra-row spacing) on some yield components (mean bulb weight, bulb dry weight, fresh biomass yield and dry biomass yield) of Adama red onion (Allium cepa L.) cultivar in 2014/15 under irrigation. The experiment was conducted using randomized complete block design with three replicates. The analyzed result using ANOVA shows significance difference among the treatments. Maximum mean bulb weight $(53.34 \mathrm{~g})$, maximum dry bulb weight $(28.13 \mathrm{~g})$, fresh biomass yield $(56.56 \mathrm{~g})$ and highest dry biomass yield $(42.00 \mathrm{~g})$ was recorded in plants spaced at $10 \mathrm{~cm}$ intra-row spacing. Therefore, it could be conclude that, under Fich condition, good quantity of Adama red onion is possible to produce with intra-row spacing of $10 \mathrm{~cm}$ which was dominant over the other treatments.
\end{abstract}

Keywords: Adama Red, Cultivar, Intra-row, Irrigation, Onion, Spacing, Yield Components

\section{Introduction}

Onion (Allium cepa L.) belongs to the genus Allium of the family Alliaceae [1]. Onion as bulb onion and/or shallot is probably cultivated sin all countries of tropical Africa including Ethiopia [2]. Onion requires adequate soil moisture due to the relatively short and small root system [3].

Onions are spread throughout the country being cultivated under both irrigated as well as rain fed conditions in different agro-climatic regions due considerably increasing its important in the daily Ethiopian diet [4]. All the plant parts are edible, but the bulbs and the lower stem sections are the most popular as seasonings or as vegetables in stews [5]. Fresh onion contains about $86.6 \%$ moisture, $11.6 \%$ carbohydrate including 6-9 soluble sugar, $1.2 \%$ protein, $0.1 \%$ fat, $0.2-0.5 \% \mathrm{Ca}, 0.05 \% \mathrm{P}$, traces of $\mathrm{Al}, \mathrm{Cu}, \mathrm{Fe}, \mathrm{Mn}, \mathrm{Zn}$, pantothenic acid and vitamins (A, B, and C) $[6,7]$. It is one of the richest sources of flavonoid in the human diet and flavonoid consumption has been associated with a reduced risk of cancer, heart disease and diabetes. In addition it is known for anti-bacterial, antiviral, anti-allergenic and antiinflammatory potential and used as preservative and medicinal plant $[5,8]$.

In Ethiopia onion crop is one of the most important vegetables produced by small hold farmers mainly as a source of cash income and for flavoring the local stew 'wet [9]. Even though the crop has great contribution both in economic and health issues its production and productivity is not scaled to the required level. Because, the use of appropriate agronomic management practices and improved technology inputs are not still highly used which have an undoubted contribution in increasing crop yield potential [10].

Quality seed yield of onion depends on genotype, locality, season and method of seed production [11]. One of the important measures to be taken in increasing the productivity of onion is determining spacing (plant population) for each agro-ecology since full package of information is required for each growing region of the country to optimize onion productivity [12]. Different cultural practices and growing environments are known to influence growth and yield of onion. So far, research in the country was mainly focused on the identification of superior cultivars of onions and adopting improved management practices [13].

In Ethiopia, the crop is believed to be more intensively consumed than any other vegetable crops and a lion share of 
$95 \%$ of the vegetables and fruits produced in the country comes from the small holder sector. Despite this, productivity of the crop remains low (10.02 $\left.\mathrm{tha}^{-1}\right)$ according to [14] which is very low compared to the world average of $19.7 \mathrm{t} \mathrm{ha}^{-1}$ [15] and is far below the potential productivity of the crop obtained in other countries such as Ireland $\left(58 \mathrm{t} \mathrm{ha}^{-1}\right)$, Korea Republic $\left(57 \mathrm{t} \mathrm{ha}^{-1}\right)$, USA $\left(55.88 \mathrm{t} \mathrm{ha}^{-1}\right)$, Spain $\left(52 \mathrm{t} \mathrm{ha}^{-1}\right)$, Chile $\left(48.50 \mathrm{tha}^{-1}\right)$ and Australia $\left(49 \mathrm{t} \mathrm{ha}^{-1}\right)$. Thus, there is a huge gap in productivity reflecting the huge scope to increase onion yields in Ethiopia [16].

Onion growers in the study area are producing both for home consumption as well as for market demand by irrigation during dry season even though, productivity of the crop is low due to poor agronomic management practices and improved technology usage. Moreover, lack of improved varieties and seed, undetermined recommended nitrogen fertilizer rate and plant spacing are the pertinent problems of the study area. Currently the nationally recommended plant spacing of $10 \mathrm{~cm}$ is used for onion production with no consideration of soil type in all onion producing potential areas [13]. However, farmers in Fich area have no experience of applying the nationally recommended plant spacing rather they practice undetermined plant spacing. In view of these, the present study was initiated to determine and suggest appropriate intra-row spacing for Adama red onion cultivar yield components for fiche district.

\section{Materials and Methods}

\subsection{Description of the Study Area}

The study was conducted at Fiche, Addis Ababa University, Selale campus Horticulture department demonstration farm. The experimental site lies on an altitude of about $2750 \mathrm{~m}$ above sea level and is located at latitude of $9^{\circ} 48^{\prime \prime} 0^{\prime \prime} \mathrm{N}$ and longitude of $38^{\circ} 42^{\prime \prime} 0^{\prime \prime} \mathrm{E}$. Fich district is characterized by highland agro-ecological zone which have a cold temperature with annual average temperature of $16.5^{\circ} \mathrm{C}$ and average rainfall of $1150 \mathrm{~mm}^{-1} \mathrm{ear}^{-1}$. The soil type of the study area is clay with $\mathrm{pH}$ of 6.4 [17].

\subsection{Experimental Material}

Adama red onion cultivar which is widely cultivated in the study area was used for the experiment as a test crop. This cultivar is a selection from onion materials imported from Sudan in 1970 which is dark red colour and firm, very pungent and flat glob shaped. It is well accepted by both producer and consumer and successfully produces by small farmer and commercial grower scattered in most regions of the country. The bulk of this cultivar is grown in Awash Valley and Lake Regions. DAP (100kg ha $\left.{ }^{-1}\right)$ and Urea (150kg urea $\mathrm{ha}^{-1}$ ) fertilizers were used as per the recommended rate for the crop uniformly in all treatments $[13,18]$.

\subsection{Treatments and Experimental Design}

A field experiment was conducted on three different level of intra-low spacing $(5,7.5$ and $10 \mathrm{~cm})$. The experiment was laid out in randomized complete blocked design (RCBD) with three replications and there was a total of 9 plots. The size of each plot was $2 \times 3 \mathrm{~m}^{2}$ containing five double rows (ridges) per plot accommodating 40 plants, 27 plant and 20 plant per row for each $5,7.5$ and $10 \mathrm{~cm}$ intra-raw spacing respectively. The distance between plots and blocks was $0.5 \mathrm{~m}$ and $1 \mathrm{~m}$ respectively.

\subsection{Experimental Procedure}

Seedlings of Adama Red onion cultivar were raised in a nursery at Addis Ababa university selale campus under plastic shade greenhouse demonstration room on raised bed with size of $1.2 \times 5 \mathrm{~m}^{2}$. Seed was obtained from Melkassa Agricultural Research center. Three raised nursery beds were prepared and seeds were sown on $10 \mathrm{~cm}$ distance between rows lightly covered with soil and mulched with grass. The mulch was removed after seedlings were fully emerged $(2-5 \mathrm{~cm}$ height from the soil). Seedlings in the nursery were managed (watering, weeding, fertilizing and pest management) as per the requirement of the crop for 45days, after which it was transplanted to the main experimental plots.

Before sowing seeds, the experimental field was plowed and harrowed by using ox drawn plowing. Large clods was broken down in order to make the land fine tilth, and then 9 plots with size of $2 \times 3 \mathrm{~m}^{2}$ was measured and laid out. The plots were leveled; furrows and ridges were made at a spacing of $40 \mathrm{~cm}$. The nursery bed was irrigated one day before uprooting the seedlings to facilitate the uprooting and subsequent good field establishment of seedlings. The field experiment was conducted under irrigation using furrow irrigation method, which is the most commonly used irrigation system in Fiche district. A four day irrigation interval was maintained for the $1^{\text {st }}$ four weeks and then extended to seven days interval [18] until 15 days to harvest, when irrigation was stopped completely. Other recommended agronomic practices like, weeding, plant protection, etc., was kept uniform for all treatments. Gap filling (re-planting) was carried out within one week to replace those seedlings which was damaged and failed after transplanting. Harvesting of onion bulbs was done when $70 \%$ plants show neck fall and bulbs was cured for four days by windrowing on the ground before topping [18].

\subsection{Data Collection}

The some yield data were collected by sampling plants randomly from the three central ridges of each plot. Accordingly, the following data were collected.

Mean bulb weight $(g)$ : was the average weight of matured bulbs of sampled plants, was taken using a sensitive balance after harvesting and curing.

Bulb dry weight $(g)$ : sampled bulbs were chopped in to small pieces with the help of stainless steel knife, samples were placed on drying materials and kept under open sun for seven days and then placed in paper bags and dried in an oven at $65^{\circ} \mathrm{C}$ for 48 hours until a constant weight was obtained. Each sample was weighed after drying using digital 
sensitive balance and the average was computed and recorded as dry weight of bulb.

Fresh biomass yield ( $g$ plant $\left.{ }^{-1}\right)$ : was recorded as the sum of the fresh weight above ground parts and bulbs of sampled plants taken as soon as the crop was harvested at maturity. Then the average fresh biomass yield per plant was calculated and recorded.

Dry biomass yield ( $g$ plant $\left.t^{-1}\right)$ : was recorded as the sum of dry weight of above ground parts and bulbs of sampled plants taken after oven drying. The average dry biological yield of sampled plants was calculated and recorded as dry biological yield per plant.

\subsection{Data Analysis}

The collected data was subjected to analysis of variance (ANOVA) and least significant difference (LSD) was used to separate means at $\mathrm{p}<0.05$ probability levels of significance.

\section{Results and Discussion}

Mean bulb weight, dry bulb weight, fresh biomass yield and dry biomass yield of Adama red onion cultivar was significantly $(\mathrm{P}<0.05)$ influenced by the effect of intra-row spacing (Table 1).

Table 1. The effect of plant spacing on mean bulb weight ( $g$ plant $\left.{ }^{-1}\right)$, dry bulb weight $\left(g\right.$ plant $\left.{ }^{-1}\right)$, fresh biomass yield $\left(g\right.$ plant $\left.^{-1}\right)$ and dry biomass yield $(g$ plant $^{1}$ ) of Adama red onion.

\begin{tabular}{lllll}
\hline intra-row spacing $(\mathbf{c m})$ & MBW & DBW & FBY & DBY \\
\hline 5 & 24.43 & 10.3 & 47.36 & 36.9 \\
7.5 & 28.69 & $13.74^{*}$ & $49.17^{\mathrm{NS}}$ & $39.11^{*}$ \\
10 & $53.34 * *$ & $28.13^{* *}$ & $56.56^{*}$ & $42^{* *}$ \\
LSD $_{0.05}$ & 14.34 & 3.40 & 5.6 & 1.91 \\
CV (\%) & 17.9 & 8.7 & 4.04 & 2.17 \\
\hline
\end{tabular}

$*$ = Statistically significant at $\mathrm{P}<0.05, * *=$ statistically highly significant at $\mathrm{P}<0.01, \mathrm{DF}=$ degree of freedom, NS $=$ non-significance, $\mathrm{MBW}=$ Mean bulb weight, DBW=Dry bulb weight, FBY $=$ Fresh biomass yield, DBY= Dry biomass yield.

\subsection{Mean Bulb Weight (g plant ${ }^{-1}$ )}

The result was once again showed the supremacy of widest spacing as it produced much heavier bulbs as compared to the other spacing. Significantly maximum bulb weight $(53.3 \mathrm{~g})$ was recorded in plants spaced at $10 \mathrm{~cm}$ (Figure 1). Nevertheless, there was no significant difference between spacing of 5 and $7.5 \mathrm{~cm}$. Production of heavier bulbs in wider spacing might be attributed to the fact that, widely spaced plants experienced little or no competition for limited environmental resources compared to closely spaced plants. This result is in agreement with observation by [19] who reported that plants spaced at $9 \mathrm{~cm}$ gave the lowest average weight for a single onion bulb while in $15 \mathrm{~cm}$ spaced plants, the weight of the bulbs was maximum. Similar result was also reported by [20] where bulbs of "Huruta" shallot planted at $20 \mathrm{~cm}$ intra-row spacing produced the highest bulb weight per plant while those planted at $10 \mathrm{~cm}$ intra-row spacing produced the lowest bulb weight per plant. The result is in accord with [21] who reported an increased mean bulb weight was observed as intra-row spacing increased from $5 \mathrm{~cm}$ to $10 \mathrm{~cm}$.

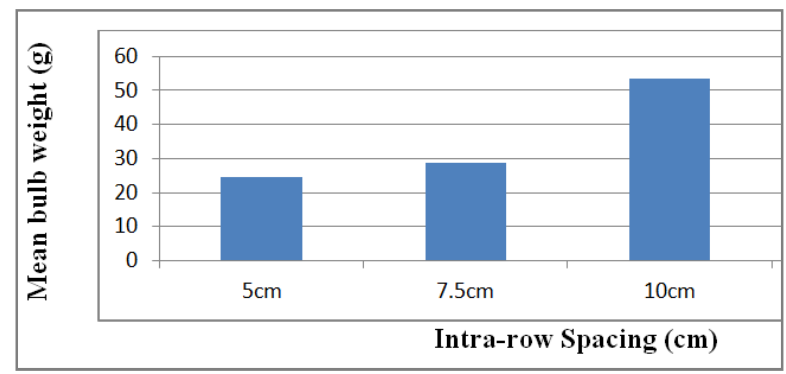

Figure 1. Effect of intra raw spacing on mean bulb weight $\left(g\right.$ plant $\left.^{-1}\right)$ of Adama red onion.

\subsection{Bulb Dry Weight (g plant $\left.{ }^{-1}\right)$}

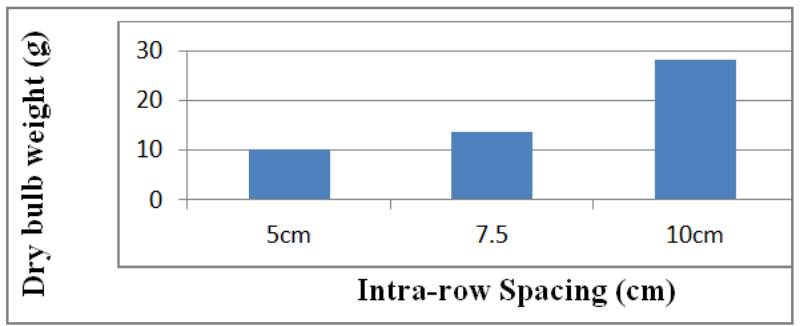

Figure 2. Effect of intra raw spacing on bulb dry weight (g plant ${ }^{-1}$ ) of Adama red onion.

The effect of intra-row spacing was also highly significantly $(\mathrm{p}<0.05)$ influenced bulb dry weight. As intrarow spacing increased from $5 \mathrm{~cm}$ to $10 \mathrm{~cm}$, the bulb dry weight was also increased from $10.3 \mathrm{~g}$ to $28.13 \mathrm{~g}$ (figure 2). This might be due to the fact that closer spacing between plants resulted in competition for nutrients, moisture and light, thus reducing amount of assimilate produced and stored in the bulbs which reduced their bulb weight. This result is in line with [19] findings who reported that plants spaced at $9 \mathrm{~cm}$ gave the lowest average weight for a single onion bulb while in plants spaced at $15 \mathrm{~cm}$; the weight of the bulb was maximum. Similar result was also reported by [20] who observed that shallot bulbs planted at $20 \mathrm{~cm}$ intra-row spacing produced greater bulb dry weight per plant than those planted at 15 and $10 \mathrm{~cm}$ intra-row spacing. Abubaker [22] also reported that pod dry weight of bean tended to be higher under the lower plant density. In crop plants, dry matter accumulation is a result of nutrient uptake and one of the measures of plant growth [23].

\subsection{Fresh Biomass Yield (g plant ${ }^{-1}$ )}

The effect of intra-row spacing was also significantly influenced bulb fresh weight. As intra-row spacing increased from $5 \mathrm{~cm}$ to $10 \mathrm{~cm}$, the bulb fresh weight was also increased from 47.3 to $86.5 \mathrm{~g}$ (Figure 3). However, there was no significant difference between spacing of 5 and $7.5 \mathrm{~cm}$. This might be due to the fact that closer spacing between plants resulted in competition for nutrients, moisture and light, thus reducing amount of assimilate produced and stored in the 
bulbs which reduced their bulb weight. Result of this study is in agreement with [20] who reported that shallot bulbs planted at $20 \mathrm{~cm}$ intra-row spacing grow more vigorously and obtained more biological yield per plant than those planted at $10 \mathrm{~cm}$ spacing. Many other authors [24, 25, 19, 26] also reported that the increased bulb weight and above ground vegetative parts of onion were obtained from plants grown in wider spacing and higher rates of nitrogen application which ultimately increased the fresh biomass yield of onion.

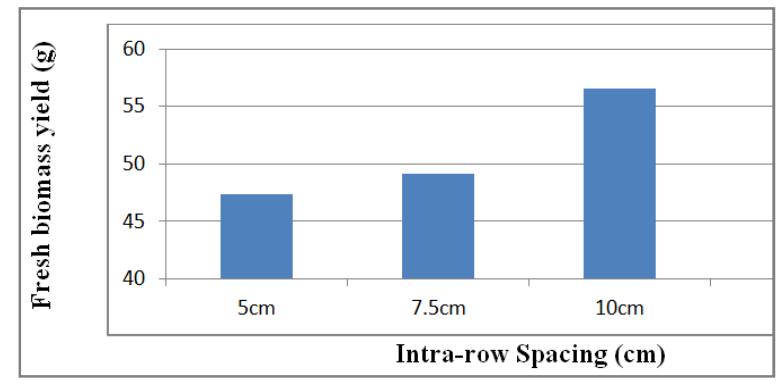

Figure 3. Effect of intra raw spacing on fresh biomass yield $\left(g\right.$ plant $\left.^{-1}\right)$ of onion.

\subsection{Dry Biomass Yield (g plant $\left.{ }^{-1}\right)$}

The effects of intra-row spacing was significantly $(\mathrm{p}<0.01)$ influenced average dry biomass yield. As intra-row spacing increased from 5 to $10 \mathrm{~cm}$, average dry biomass yield was also increased from $36.93 \mathrm{~g}$ to $42 \mathrm{~g}$ (Figure 4). The result is in line with the findings of [27] who noticed that onion bulb size and weight increases with increasing inter, and intra-row spacing, but recorded lower total bulb yield that increases with closer spacing. Densely populated plants produced lower bulb weight as compared to thinly populated plants. Increasing plant spacing resulted in heavier onion bulbs [28] Mean bulb weight and plant height decreased as population density increased [29]. Jan et al. [30] also reported that at narrower spacing $(17 \times 4.5 \mathrm{~cm})$ minimum bulb weight was produced.

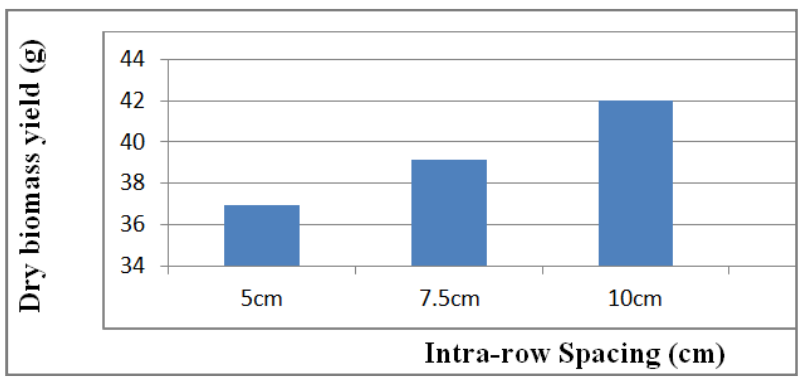

Figure 4. Effect of intra-raw spacing on dry biomass yield ( $g$ plant $\left.{ }^{-1}\right)$ of Adama red onion.

\section{Conclusion}

Onion is among the most widely cultivated crop in Ethiopia and is rapidly becoming a popular vegetable crop by producers and consumers. In Fiche district, onion is produced in the same way as other parts of the country for home and as a cash crop by irrigation. However, lack of improved varieties and inappropriate production practices and absence of technologies are the major bottleneck of onion production and productivity in the area. Therefore, a field experiment was conducted at Addis Ababa University, Selale campus horticulture department demonstration farm to determine appropriate intra-row spacing of Adama red onion for the area. Results of the field experiment revealed that the effects of intra-row spacing showed a significant effect on bulb length, mean bulb weight, bulb dry weight, fresh biomass yield and dry biomass yield.

Therefore, it could be conclude that, under Fich condition, good quantity of Adama red onion is possible to produce with intra-row spacing of $10 \mathrm{~cm}$. However, this intra-row spacing cannot be generalized for all onion cultivars and locations in areas of Fiche district. Therefore, the experiment should be repeated over locations and seasons by including intra-row spacings narrower than $5 \mathrm{~cm}$ as well as higher than $10 \mathrm{~cm}$.

\section{References}

[1] Hanelt P (1990). "Taxonomy, Evolution, and History." In Onions and Allied Crops, edited by Haim D. Rabinowitch and James L. Brewster, 1-26. Boca Raton, Fla.: CRC Press.

[2] Grubben JH, Denton DA (2004). Plant resources of tropical Africa. PROTA Foundation, Wageningen; Back huys, Leiden; CTA, Wageningen.

[3] Kebede W (2003). Shallot (Allium cepa var. ascalonicum) Responses to Plant Nutrients and Soil Moisture in a subhumid Tropical Climate. Doctoral Thesis. Swedish university of Agricultural Sciences, Alnarp.

[4] Lemma D, Herath E (1992). Agronomic Studies on Allium. Pp.139-145. In: Horticultural Research and Development in Ethiopia. 1-3 December, 1992. Institute of Agricultural research and food and Agricultural Organization. Addis Ababa, Ethiopia.

[5] MoARD (Ministry of Agriculture and rural Development) (2009). Rural Capacity Building project. Course for Training of trainers on improved horticultural crop technologies. pp. 5-19.

[6] El-Tantawy EM, El-Beik AK (2009). Relationship between growth, yield and storability of onion (Allium cepa L.) with fertilization of nitrogen, sulphur and copper under calcareous Soil Conditions. Research Journal of Agriculture and Biological Sciences, 5(4): $\quad 361-371$. http://www.insipub.com/rjabs/2009/361-371.pdf. Accessed June, 2010.

[7] Malik MN (2000). Horticulture Biotech Books .Delhi. 586p.

[8] Vohra SB, Rizaman M, Khan JA (1994). Medical uses of common Indian vegetables. Planta Medea., 23(4): 381-393.

[9] Gupta RP, Srivastava KJ, Pandey UB, Midmore DJ (1994). Diseases and insect pests of onion in India. Acta Horticult. 358: $265-372$.

[10] Weldemariam SG, Kebede W, Wassu M (2015). Growth Parameters of Onion (Allium cepa L. var. Cepa) as Affected by Nitrogen Fertilizer Rates and Intra-row Spacing Under Irrigation in Gode, South-Eastern Ethiopia. Agriculture, Forestry and Fisheries. Vol. 4, No. 6, pp. 239-245. doi: 10.11648/j.aff.20150406.11. 
[11] Esmat JA, Md Torikul Islam AM Farooque (2013). Effect of Vernalization on seed production of onion. Agriculture, Forestry and Fisheries. Vol. 2, No. 6, pp. 212-217. doi:10.11648/j.aff.20130206.12.

[12] Lemma D, Shimeles A (2003). Research experiences in onions production. Research report No. 55, EARO, Addis Ababa, Ethiopia.

[13] CSA (Central Statistics Agency) (2013). Area and production of major crops. Agricultural sample survey 2012/2013, private peasant holdings, Meher season, Statistical Bulletin 532, Addis Ababa.

[14] FAO (Food and Agricultural Organization) (2012). Crop production data: http:/www.faostat.fao.org, Accessed, September 17, 2013.

[15] Negasi T (2014). Onion production practices and response of the crop to fertilizer application in central rift valley of Ethiopia. Ph.D. Dissertation submitted to the school of graduate studies, Haramaya University, Ethiopia.

[16] Fiche Meteorological station, (2015). Annual data report.

[17] EARO (Ethiopian Agricultural research Organization), 2004. Directory of released crop varieties and their recommended cultural practice, Addis Ababa.

[18] Khan H, Iqbal M, Ghaffoor A, Waseem K (2002). Effect of various plant spacing and different nitrogen levels on growth and yield of onion (Allium cepa L.). Online J. Biol. Sci., 2: 545-547.

[19] Dereje A, Derbew B, Getachew T (2012). Influence of bulb topping and intra row spacing on yield and quality of some shallot (Allium Cepa Var. Aggregatum) varieties at Aneded woreda, western Amhara. Afri. J. Plant Sci., 6(6): 190-202.

[20] Kahsay Y, Fetien A, and Derbew B (2013). Intra-row spacing effect on shelf life of onion varieties (Allium cepa L.) at
Aksum, Northern Ethiopia. J. Plant breeding and crop Sci., 5(6): $127-136$.

[21] Abubaker S (2008). Effect of plant density on flowering date, yield and quality attribute of Bush Beans (Phaseolus Vulgaris L.) under Center Pivot Irrigation System. Amer. J. Agri. and Biol. Sci., 3(4): 666-668.

[22] Noggle GR, Fritz GR (1983). Introductory Plant Physiology $2^{\text {nd }}$ edition. Prentice Hall Inc. Engle Wood Cliffs New Jersey, p. 625 .

[23] Shaikh MA, Ansari AH, Qayyum SM, Baloch MB, Qayyum SA, Hassan AM (1987). Technical report on effect of nitrogen doses on the growth and crop yield of onion. Pak. Agri., 9: 3547.

[24] Patel IJ, Patel AT (1990). Effect of nitrogen and phosphorus levels on growth and yield of onion. (Allium cepa L.) Cultivar Pusa Red Res. Gujarat Agric. Univ. 15: 1-heikh Univ., 38(1): 171-187.

[25] Akuon J (2004). Effect of plant density and manure on yield and yield components of common onion (Allium cepa L.)Var. Nsukka Red. Nigerian J. Hort. Sci., 9: 43-48.

[26] Rashid MA, Rashid MM (1978). The effect of spacing on the yield of onion. Hort. Abst. 48: 481.

[27] Jilani M.S, Khan MQ, Rahman S., (2009). Planting densities effect on yield and yield components of onion (Allium cepa L.). J. Agric. Res. 47(4): 397-404.

[28] Mohamed GH (1988). Effect of Plant Population Densities on Yield and Quality of White Dehydration Onion in the Northern Sudan: http://www.arcsudan.sd/, accessed, April 2015.

[29] Jan NE, Wazir FK, Ibrar M, Mohammed H, Ali AR (2003). Effect of Different Inter and Intra-row Spacing on the Growth and Yield of different Cultivars of Onion. Sarhad J. Agric. 19: 4. 